\title{
Variations in Leaf Chlorophyll Concentration in Croton Plants (Codiaeum variegatum L.) Cultivar Gelatik at a Different Leaf Age
}

\author{
Jieni Trivalen Djangaopa ${ }^{1)}$, Susan M. Mambu ${ }^{1)}$, Song Ai Nio ${ }^{\left.1^{*}\right)}$ \\ ${ }^{1)}$ Program Studi Biologi, Fakultas Matematika dan Ilmu Pengetahuan Alam, \\ Universitas Sam Ratulangi Manado \\ "Corresponding author: niosongai@unsrat.ac.id
}

(Article History: Received 13-05-2020; Accepted 15-06-2020; Published 28-06-2020

\begin{abstract}
The leaf color of croton plants (Codiaeum variegatum L.) cv. Gelatik varies from green, yellow until red. This study aimed to evaluate the variations of leaf chlorophyll concentration in croton plants cv. Gelatik at a different leaf age. The branches of the stem with 9-10 leaves were three times sampled from croton trees grown in Kalasey Dua Village, Mandolang District, Minahasa Regency. All leaves of each branch were picked sequentially, from the oldest leaf in the lowest position to the youngest leaf in the terminal of the branch. Leaf colors were determined using a color grab program downloaded from the Google Play Store. Each leaf was extracted using 95\% ethanol and the chlorophyll concentration was measured using the Nano Usage spectrophotometer-3000 at the wavelengths of 649 and $665 \mathrm{~nm}$. The results of this study indicated that total chlorophyll concentration in croton leaves was $3.01-33.14 \mathrm{mg} / \mathrm{L}$, chlorophyll a concentration was $0.03-3.90 \mathrm{mg} / \mathrm{L}$, and chlorophyll b concentration was $18.77-3125 \mathrm{mg} / \mathrm{L}$. The chlorophyll concentrations in the old leaf with brown-red color was higher than other leaves with different color.
\end{abstract}

Keywords: croton leaf; chlorophyll concentration; leaf age

\section{Konsentrasi Klorofil Daun pada Tanaman Puring (Codiaeum variegatum L.) Varietas Gelatik dengan Umur Daun yang Berbeda}

\begin{abstract}
ABSTRAK
Tanaman puring (Codiaeum variegatum L.) varietas gelatik menunjukkan variasi warna daun, yaitu hijau, kuning, dan merah. Penelitian ini bertujuan untuk mengevalusi ada tidaknya variasi konsentrasi klorofil daun pada tanaman puring varietas gelatik dengan umur daun yang berbeda. Pengambilan sampel dilakukan sebanyak tiga kali, yaitu cabang tanaman puring varietas gelatik dengan 9-10 daun yang diambil dari pohon puring di Desa Kalasey Dua, Kecamatan Mandolang, Kabupaten Minahasa. Semua daun puring pada cabang pohon tersebut dipetik secara berurutan, dari daun tertua yang berada di posisi bawah sampai daun termuda di terminal cabang pohon tersebut. Warna daun ditentukan dengan menggunakan program color grab yang di- download dari Google Play Store. Setelah daun diekstrak dengan alkohol 95\%, konsentrasi klorofil diukur dengan menggunakan spektrofotometer-3000 nano Usage pada panjang gelombang 649 dan 665 $\mathrm{nm}$. Hasil penelitian ini menunjukkan bahwa konsentrasi klorofil total pada daun puring bervariasi antara 3,01-33,14 mg/L, konsentrasi klorofil a bervariasi antara 0,03-3,90 mg/L dan konsentrasi klorofil b bervariasi antara 18,77-31,25 mg/L. Konsentrasi klorofil pada daun tua yang berwarna coklat-merah cenderung lebih tinggi dibandingkan dengan pada daun dengan warna lain.
\end{abstract}

Kata kunci: Daun puring; konsentrasi klorofil; umur daun

\section{PENDAHULUAN}

Tanaman puring (Codiaeum variegatum L.) yang juga dikenal dengan nama croton merupakan tanaman yang dapat digunakan sebagai tanaman penghias pagar dan pekarangan rumah. Tanaman ini banyak ditemukan di daerah beriklim tropis dan subtropis. Beberapa varietas tanaman puring telah dikembangkan dengan warna daun yang 
bervariasi mulai dari hijau, kuning, merah, ungu, dan campuran berbagai warna tersebut (Gogahu et al., 2016; Nio et al., 2018). Tanaman ini banyak diminati oleh masyarakat, karena tanaman puring memiliki warna daun yang menyolok dan bercorak. Variasi warna daun disertai dengan rimbunnya daun yang tumbuh sehingga memberikan kesan asri yang menyejukkan dan tanaman ini mudah untuk dirawat dan dapat dibudidayakan (Muzayyinah, 2003; Upadani et al., 2013; Nio et al., 2018).

Tanaman yang termasuk anggota suku Euphorbiaceae ini merupakan tumbuhan bergetah, tergolong perdu dengan tinggi antara 1-3 m, batang bercabang banyak, bulat, berkayu, berkulit tipis, dan kehijauan pada waktu muda lalu berwarna coklat setelah tua. Bentuk daun tanaman ini juga bervariasi, ada yang panjang, lonjong, dan bergelombang. Daun puring merupakan daun tunggal berseling, tangkai daun membulat, panjang 1-4 $\mathrm{cm}$. Bentuk daun puring beragam yaitu lanset, bulat telur, dan memanjang dengan permukaan mengkilap dan licin serta berukuran lebar 2-10 $\mathrm{cm}$ dan panjang 5-38 cm (Webster, 1992).

Pigmen pada tanaman dapat berupa klorofil, karotenoid, dan antosianin (Kumari et al., 2012). Klorofil adalah pigmen yang berwarna hijau yang terdapat dalam kloroplas pada jaringan daun. Klorofil berperan untuk mengabsorpsi, menangkap cahaya dan mengubah energi cahaya menjadi energi kimia yang akan dimanfaatkan oleh tumbuhan. Pada dasarnya ada dua kelompok utama klorofil, yaitu klorofil a dan b. Klorofil a berwarna hijau, sedangkan klorofil b berwarna hijau kebiruan (Aryulina et al., 2006). Kandungan klorofil daun pada suatu tanaman bervariasi dan hal ini dipengaruhi oleh umur daun, posisi daun pada suatu tanaman dan varietas tanaman (Sukendro \& Sugiarto, 2012; Mustafa et al., 2015).

Tanaman puring $(C$. variegatum $\mathrm{L}$.) varietas gelatik menunjukkan variasi warna daun, yaitu hijau, kuning, dan merah. Bentuk daun puring bervariasi dari memanjang, oval, dan tepi bergelombang (Webster, 1992). Perbedaan warna daun ini dapat disebabkan oleh perbedaan kandungan pigmen daun, termasuk pigmen klorofil. Gogahu et al., (2016) mengukur konsentrasi klorofil daun yang tertua dan termuda pada beberapa tanaman puring hasil perbanyakan stek yang masih berumur 3 bulan. Kajian variasi konsentrasi klorofil pada semua daun yang tumbuh pada suatu cabang tanaman puring ini dengan umur yang berbeda belum dilakukan. Oleh sebab itu, dilakukan penelitian yang bertujuan untuk mengevaluasi ada tidaknya variasi konsentrasi klorofil daun tanaman puring varietas gelatik dengan umur daun yang berbeda. Informasi yang akan diperoleh dari penelitian ini diharapkan dapat dipakai sebagai data pembanding untuk penelitian yang berhubungan dengan konsentrasi klorofil dan juga pigmen lainnya pada suatu tumbuhan.

\section{METODE PENELITIAN}

\section{Alat dan Bahan}

Alat-alat yang digunakan dalam penelitian adalah botol kaca coklat $100 \mathrm{~mL}$, gelas ukur, mortar dan pestel, alat tulismenulis, timbangan analitik, corong, kertas label, gunting, kamera digital, termohigrometer, program color grab, spektrofotometer-3000 nano Usage, coolbox, dan kantong plastik.

Bahan-bahan penelitian yang digunakan adalah daun tanaman puring $(C$. variegatum L.) varietas gelatik, alkohol 95\%, kertas saring, dan tissue.

\section{Prosedur Penelitian}

\section{Pengambilan Sampel Daun}

Sampel daun diambil dari pohon puring dengan tahapan kerja sebagai berikut:

1. Cabang batang tanaman puring varietas gelatik yang mempunyai beberapa daun (Gambar 1) diambil dari pohon puring yang tumbuh di Desa Kalasey Dua, Kecamatan Mandolang, Kabupaten Minahasa.

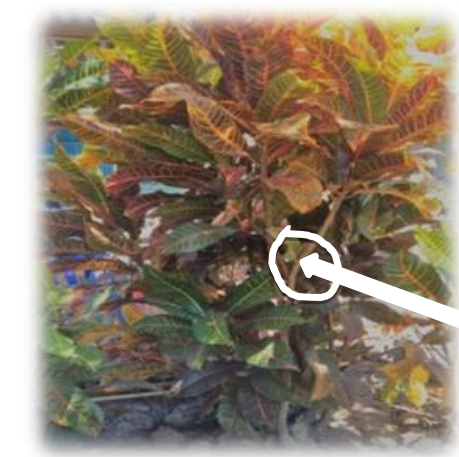

Gambar 1. Sampel cabang pohon dengan beberapa daun. 
2. Semua daun puring pada cabang pohon tersebut dipetik secara berurutan, dari daun yang berada di posisi bawah (daun ke-1 atau tertua) sampai daun terakhir di terminal cabang pohon tersebut (daun termuda).

3. Setiap daun pada cabang pohon tersebut diberi label dan diletakkan dalam kantung plastik, kemudian semua sampel daun tersebut dimasukkan ke dalam coolbox.

4. Selanjutnya sampel tersebut dibawa ke laboratorium untuk ditentukan warnanya dan konsentrasi klorofilnya.

5. Temperatur dan kelembaban udara di lokasi diukur pada saat pengambilan sampel dengan menggunakan termohigrometer.

6. Warna daun ditentukan dengan menggunakan program color grab didownload dari Google Play Store.

\section{Penentuan Konsentrasi Klorofil Daun Puring (C. variegatum L.)}

Tahapan-tahapan kerja dalam penentuan konsentrasi klorofil daun puring adalah sebagai berikut:

1. Daun puring pada setiap posisi daun yang berbeda diambil masing-masing sebanyak $0,5 \mathrm{~g}$, pada bagian helaian daun (lamina). seperti terlihat pada Gambar 2.

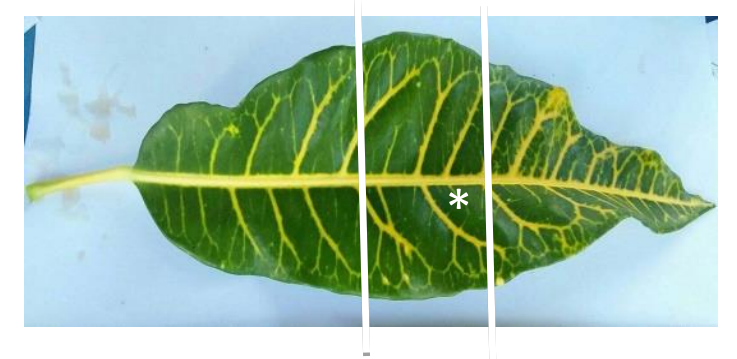

Gambar 2. Bagian helaian daun yang diambil (*) untuk ekstraksi dan pengukuran klorofil.

2. Selanjutnya helaian daun dipotong-potong, dimasukkan ke dalam mortar dan dihaluskan dengan pestel, kemudian diekstraksi dengan $50 \mathrm{~mL}$ alkohol $95 \%$ sampai semua klorofil terlarut.

3. Ekstrak klorofil disaring dan filtrat ditampung dalam botol gelap berukuran $100 \mathrm{~mL}$.

4. Konsentrasi klorofil diukur dengan menggunakan spektrofotometer-3000 nano Usage pada panjang gelombang 649 dan $665 \mathrm{~nm}$. Konsentrasi klorofil total, klorofil a, dan klorofil b dapat dihitung dengan rumus dari Sasmitamihardja (1990) sebagai berikut:

$$
\begin{aligned}
& \text { Klorofil total }(\mathrm{mg} / \mathrm{L})=20 \mathrm{OD}_{649}+ \\
& \qquad 6,1 \mathrm{OD}_{665} \\
& \text { Klorofil a }(\mathrm{mg} / \mathrm{L}) \quad=13,7 \mathrm{OD}_{665}- \\
& 5,76 \mathrm{OD}_{649} \\
& \text { Klorofil b }(\mathrm{mg} / \mathrm{L}) \quad=25,8 \mathrm{OD}_{649}-
\end{aligned}
$$

\section{$7,60 \mathrm{OD}_{665}$}

Keterangan: OD (optical density $=$ nilai absorbansi)

\section{HASIL DAN PEMBAHASAN}

Evaluasi warna daun dan konsentrasi klorofil daun pada tanaman puring $(C$. variegatum $\mathrm{L}$.) varietas gelatik dengan umur daun yang berbeda dilakukan dengan tiga kali pengambilan sampel cabang dari satu pohon yang sama. Sampel cabang pohon yang pertama dan ke dua masing-masing mempunyai 9 helai daun, sedangkan sampel cabang pohon yang ke tiga mempunyai 10 helai daun. Untuk memudahkan penyebutan umur daun dalam pembahasan selanjutnya digunakan acuan penamaan daun berumur muda, sedang, dan tua. Daun pertama adalah daun yang terletak pada pangkal cabang dan ditetapkan sebagai daun tertua, sedangkan daun terakhir (urutan ke sembilan dan ke sepuluh) adalah daun yang terletak pada ujung cabang yang dikategorikan sebagai daun termuda dilihat pada Tabel 1 dan Gambar 3. 
Tabel 1. Nomor dan kategori umur daun pada cabang pohon puring

\begin{tabular}{ll}
\hline Cabang sampel 1 dan 2 & Cabang sampel 3 \\
\hline Daun ke-1 sampai 3: tua & Daun ke-1 sampai 3: tua \\
Daun ke-4 sampai 6: sedang & Daun ke-4 sampai 6: sedang \\
Daun ke-7 sampai 9: muda & Daun ke-7 sampai 10: muda \\
\hline
\end{tabular}

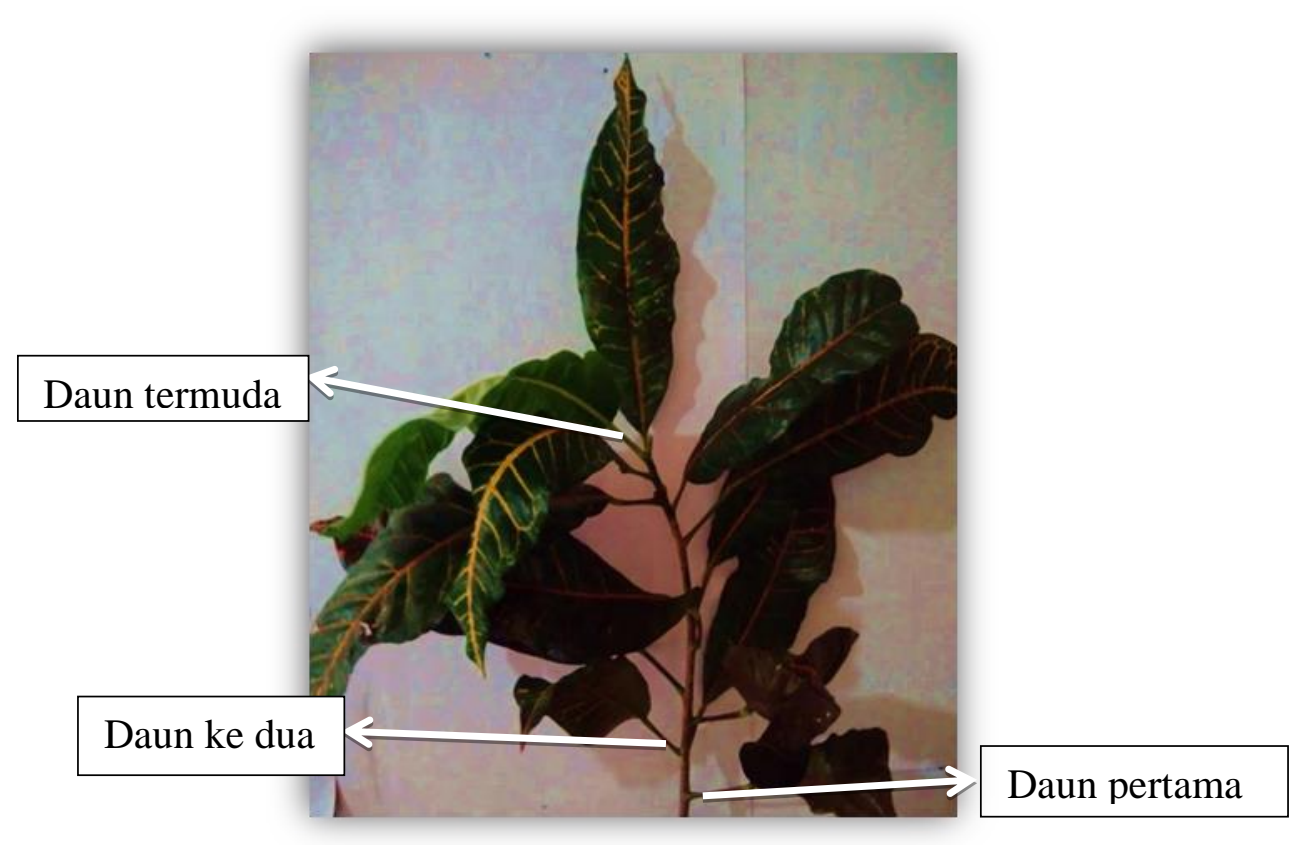

Gambar 3. Cabang puring dan penomoran daun puring.

Cabang sampel yang pertama mempunyai 9 helai daun dengan sebaran warna jingga, kuning, dan hijau. Sebaran warna dan konsentrasi klorofil daun disajikan Tabel 2. Secara umum konsentrasi klorofil b pada kesembilan daun puring ini lebih besar daripada konsentrasi klorofil a. Konsentrasi klorofil total berkisar antara $3,78 \mathrm{mg} / \mathrm{L}$ pada daun ke-9 (berwarna kuning) dan 23,04 mg/L pada daun ke-5 (berwarna hijau tua). Konsentrasi klorofil a berkisar dari $0,33 \mathrm{mg} / \mathrm{L}$ pada daun ke-8 (berwarna kuning-hijau) sampai dengan 3,90 $\mathrm{mg} / \mathrm{L}$ pada daun ke-3 (berwarna kuning). Kisaran konsentrasi klorofil $\mathrm{b}$ adalah $2,79 \mathrm{mg} / \mathrm{L}$ pada daun ke-9 (berwarna kuning) sampai dengan 22,52 $\mathrm{mg} / \mathrm{L}$ pada daun ke-5 (berwarna hijau tua). Konsentrasi klorofil total, klorofil a, dan klorofil b yang rendah diamati pada daun dengan kategori umur muda, yakni daun ke- 8 (berwarna kuning-hijau) dan ke-9 (berwarna kuning). Konsentrasi klorofil total dan klorofil $b$ yang tinggi diamati pada daun dengan kategori umur sedang, yaitu daun ke5 (berwarna hijau gelap). Konsentrasi klorofil a yang tinggi diamati pada daun dengan kategori umur tua, yaitu daun ke-3 (berwarna kuning). 
Tabel 2. Warna daun dan konsentrasi klorofil daun tanaman puring dengan umur daun yang berbeda pada cabang sampel pertama.

\begin{tabular}{|c|c|c|c|c|c|}
\hline $\begin{array}{c}\text { Daun } \\
\text { Ke- }\end{array}$ & $\begin{array}{l}\text { Foto } \\
\text { Daun } \\
\end{array}$ & Warna Daun & $\begin{array}{c}\text { [Klorofil total] } \\
(\mathrm{mg} / \mathrm{L})\end{array}$ & $\begin{array}{c}\text { [Klorofil a] } \\
(\mathrm{mg} / \mathrm{L})\end{array}$ & $\begin{array}{c}\text { [Klorofil b] } \\
(\mathrm{mg} / \mathrm{L})\end{array}$ \\
\hline 1 & & $\begin{array}{l}\text { Orange:Yellow } \\
\text { (Jingga-Kuning) }\end{array}$ & 12,99 & 0,80 & 12,21 \\
\hline 2 & & $\begin{array}{l}\text { Orange:Yellow } \\
\text { (Jingga-Kuning) }\end{array}$ & 9,41 & 1,93 & 7,50 \\
\hline 3 & & Yellow (Kuning) & 18,12 & 3,90 & 14,25 \\
\hline 4 & & $\begin{array}{c}\text { Dark } \\
\text { Green:Yellow } \\
\text { (Hijau tua- } \\
\text { Kuning) }\end{array}$ & 11,47 & 0,58 & 10,92 \\
\hline 5 & & $\begin{array}{l}\text { Dark Green } \\
\text { (Hijau tua) }\end{array}$ & 23,04 & 0,57 & 22,52 \\
\hline 6 & & $\begin{array}{l}\text { Yellow:Orange } \\
\text { (Kuning-Jingga) }\end{array}$ & 5,42 & 1,03 & 4,40 \\
\hline 7 & & $\begin{array}{c}\text { Dark } \\
\text { Yellow:Green } \\
\text { (Kuning tua- } \\
\text { Hijau) }\end{array}$ & 16,94 & 1,41 & 15,56 \\
\hline 8 & & $\begin{array}{l}\text { Yellow:Green } \\
\text { (Kuning-Hijau) }\end{array}$ & 5,04 & 0,33 & 4,72 \\
\hline 9 & & Yellow (Kuning) & 3,78 & 1,00 & 2,79 \\
\hline
\end{tabular}

Cabang sampel yang ke dua mempunyai 9 helai daun dengan sebaran warna jingga, kuning, dan hijau. Sebaran warna dan konsentrasi klorofil daun disajikan pada Tabel 3. Secara umum konsentrasi klorofil $b$ pada kesembilan daun puring ini lebih besar daripada konsentrasi klorofil a. Konsentrasi klorofil total berkisar antara 3,01 $\mathrm{mg} / \mathrm{L}$ pada daun ke-9 (berwarna hijaukuning) dan 19,30 $\mathrm{mg} / \mathrm{L}$ pada daun ke-3 (berwarna kuning tua-jingga). Konsentrasi klorofil a berkisar dari $0,12 \mathrm{mg} / \mathrm{L}$ pada daun ke-9 (berwarna hijau-kuning) sampai dengan $1,39 \mathrm{mg} / \mathrm{L}$ pada daun ke-6 (berwarna kuninghijau). Kisaran konsentrasi klorofil $b$ adalah 2,76 mg/L pada daun ke-8 (berwarna jinggakuning) sampai dengan $18,77 \mathrm{mg} / \mathrm{L}$ pada daun ke-3 (berwarna kuning tua-jingga). Konsentrasi klorofil total, klorofil a, dan klorofil b yang rendah diamati pada daun dengan kategori umur muda, yakni daun ke- 8 (berwarna jingga-kuning) dan ke-9 (berwarna 
hijau-kuning). Konsentrasi klorofil total dan klorofil b yang tinggi diamati pada daun dengan kategori umur tua, yaitu daun ke-3 (berwarna kuning tua-jingga). Konsentrasi klorofil a yang tinggi diamati pada daun dengan kategori umur tua, yaitu daun ke-6 (berwarna kuning-hijau).

Tabel 3. Warna daun dan konsentrasi klorofil daun tanaman puring dengan umur daun yang berbeda pada cabang sampel kedua.

\begin{tabular}{|c|c|c|c|c|c|}
\hline $\begin{array}{c}\text { Daun } \\
\text { Ke- }\end{array}$ & $\begin{array}{l}\text { Foto } \\
\text { Daun }\end{array}$ & Warna Daun & $\begin{array}{c}\text { [Klorofil total] } \\
(\mathrm{mg} / \mathrm{L})\end{array}$ & $\begin{array}{c}\text { [Klorofil a] } \\
(\mathrm{mg} / \mathrm{L})\end{array}$ & $\begin{array}{c}\text { [Klorofil b] } \\
\quad(\mathrm{mg} / \mathrm{L})\end{array}$ \\
\hline 1 & & $\begin{array}{l}\text { Yellow:Green } \\
\text { (Kuning:Hijau) }\end{array}$ & 12,68 & 0,60 & 12,1 \\
\hline 2 & & $\begin{array}{l}\text { Yellow:Orange } \\
\text { (Kuning:Jingga) }\end{array}$ & 12,58 & 0,29 & 12,32 \\
\hline 3 & & $\begin{array}{l}\text { Dark Yellow:Orange } \\
\text { (Kuning tua:Jingga) }\end{array}$ & 19,30 & 0,56 & 18,77 \\
\hline 4 & & $\begin{array}{l}\text { Orange:Yellow } \\
\text { (Jingga-Kuning) }\end{array}$ & 14,12 & 0,69 & 13,45 \\
\hline 5 & & $\begin{array}{l}\text { Yellow:Green } \\
\text { (Kuning:Hijau) }\end{array}$ & 9,49 & 0,19 & 9,32 \\
\hline 6 & & $\begin{array}{l}\text { Yellow:Green } \\
\text { (Kuning:Hijau) }\end{array}$ & 14,45 & 1,39 & 13,09 \\
\hline 7 & & $\begin{array}{l}\text { Dark Green:Yellow } \\
\text { (Hijau tua-Kuning) }\end{array}$ & 10,98 & 0,49 & 10,51 \\
\hline 8 & & $\begin{array}{l}\text { Orange:Yellow } \\
\text { (Jingga:Kuning) }\end{array}$ & 3,20 & 0,44 & 2,76 \\
\hline 9 & & $\begin{array}{l}\text { Green:Yellow } \\
\text { (Hijau-kuning) }\end{array}$ & 3,01 & 0,12 & 2,89 \\
\hline
\end{tabular}


Tabel 4. Warna daun dan konsentrasi klorofil daun tanaman puring dengan umur daun yang berbeda pada cabang sampel kedua

\begin{tabular}{|c|c|c|c|c|c|}
\hline $\begin{array}{c}\text { Daun } \\
\text { Ke- }\end{array}$ & $\begin{array}{l}\text { Foto } \\
\text { Daun }\end{array}$ & Warna Daun & $\begin{array}{l}\text { [Klorofil total] } \\
(\mathrm{mg} / \mathrm{L})\end{array}$ & $\begin{array}{c}\text { [Klorofil a] } \\
(\mathrm{mg} / \mathrm{L})\end{array}$ & $\begin{array}{l}\text { [Klorofil b] } \\
\quad(\mathrm{mg} / \mathrm{L})\end{array}$ \\
\hline 1 & & $\begin{array}{c}\text { Brown:Red } \\
\text { (Coklat:Merah) }\end{array}$ & 33,14 & 1,97 & 31,23 \\
\hline 2 & & $\begin{array}{c}\text { Brown:Red } \\
\text { (Coklat:Merah) }\end{array}$ & 24,18 & 0,64 & 23,58 \\
\hline 3 & & $\begin{array}{l}\text { Orange:Yellow } \\
\text { (Jingga:Kuning) }\end{array}$ & 17,33 & 1,22 & 16,14 \\
\hline 4 & & $\begin{array}{l}\text { Brown:Orange } \\
\text { (Coklat:Jingga) }\end{array}$ & 4,96 & 0,25 & 4,72 \\
\hline 5 & & $\begin{array}{l}\text { Orange:Yellow } \\
\text { (Jingga:Kuning) }\end{array}$ & 10,02 & 1,92 & 8,11 \\
\hline 6 & & $\begin{array}{l}\text { Dark Green:Yellow } \\
\text { (Hijau tua:Kuning) }\end{array}$ & 21,30 & 0,76 & 20,58 \\
\hline 7 & & $\begin{array}{l}\text { Orange: Yellow } \\
\text { (Jingga:Kuning) }\end{array}$ & 24,71 & 3,25 & 21,50 \\
\hline 8 & & $\begin{array}{l}\text { Green:Yellow } \\
\text { (Hijau:Kuning) }\end{array}$ & 14,26 & 0,51 & 13,78 \\
\hline 9 & & $\begin{array}{l}\text { Dark Green:Yellow } \\
\text { (Hijau tua:Kuning) }\end{array}$ & 12,84 & 1,11 & 11,75 \\
\hline 10 & 87 & $\begin{array}{l}\text { Dark Yellow:Orange } \\
\text { (Kuning tua:Jingga) }\end{array}$ & 4,03 & 0,03 & 4,01 \\
\hline
\end{tabular}

Cabang sampel yang ke tiga mempunyai 10 helai daun dengan sebaran warna coklat, merah, jingga, kuning, dan hijau. Sebaran warna dan konsentrasi klorofil daun disajikan pada Tabel 4. Secara umum konsentrasi klorofil b pada kesepuluh daun puring ini lebih besar daripada konsentrasi klorofil a. Konsentrasi klorofil total berkisar dari 4,03 $\mathrm{mg} / \mathrm{L}$ pada daun ke-10 (berwarna kuning tua-jingga) sampai dengan 33,14 $\mathrm{mg} / \mathrm{L}$ pada daun pertama (berwarna coklatmerah). Konsentrasi klorofil a berkisar antara $0,03 \mathrm{mg} / \mathrm{L}$ pada daun ke-10 (berwarna kuning tua-jingga) sampai dengan $3,25 \mathrm{mg} / \mathrm{L}$ pada daun ke-7 (berwarna jingga-kuning). Kisaran konsentrasi klorofil $\mathrm{b}$ adalah $4,01 \mathrm{mg} / \mathrm{L}$ pada 
daun ke-10 (berwarna kuning tua-jingga) dan $31,23 \mathrm{mg} / \mathrm{L}$ pada daun pertama (berwarna coklat-merah). Konsentrasi klorofil total, klorofil a, dan klorofil b yang rendah diamati pada daun yang termuda, yakni daun ke-10 (berwarna kuning tua-jingga). Konsentrasi klorofil total dan klorofil $b$ yang tinggi diamati pada daun dengan kategori umur tua, yaitu daun pertama (berwarna coklat-merah). Konsentrasi klorofil a yang tinggi diamati pada daun dengan kategori umur muda, yaitu daun ke-7 (berwarna jingga-kuning).

Temperatur dan kelembaban udara diukur pada saat pengambilan sampel cabang pertama, ke dua, dan ke tiga. Sampel tersebut diambil dari pohon puring yang sama tetapi dengan waktu pengambilan yang berbeda. Temperatur rata-rata adalah $28,6{ }^{\circ} \mathrm{C}$ dan kelembaban $70 \%$ pada pengambilan sampel cabang ke-1. Temperatur rata-rata adalah $30,8{ }^{\circ} \mathrm{C}$ dan kelembaban $70 \%$ pada pengambilan sampel cabang ke-2. Temperatur rata-rata $29,5{ }^{\circ} \mathrm{C}$ dan kelembaban $71 \%$ pada pengambilan sampel cabang ke-3.

Hasil penelitian ini menunjukkan bahwa konsentrasi klorofil total, klorofil a, dan klorofil $b$ yang rendah diamati pada daun dengan kategori umur muda. Konsentrasi klorofil pada daun tertua pada cabang sampel yang ke tiga dan berwarna coklat merah cenderung lebih tinggi dibandingkan dengan pada daun yang berwarna lain. Hasil penelitian sejalan dengan yang dilaporkan oleh Pratama \& Laily (2015), yaitu umur daun pada tanaman mempengaruhi konsentrasi klorofil daun.

Variasi pigmen daun dapat dipengaruhi oleh faktor internal dan kondisi lingkungan di sekitarnya. Konsentrasi klorofil dipengaruhi oleh beberapa faktor antara lain gen, cahaya, air, unsur hara $(\mathrm{N}, \mathrm{Mg}, \mathrm{Fe}, \mathrm{Mn}$, $\mathrm{Cu}, \mathrm{Zn}, \mathrm{S}$ dan $\mathrm{O}$ ), umur daun dan tahapan fisiologi suatu tanaman (Dwidjoeseputro, 1994). Kandungan pigmen daun bervariasi tergantung pada spesies (Sumanta et al., 2014). Konsentrasi klorofil daun puring akan meningkat dengan bertambahnya umur daun tersebut. Hal ini berarti bahwa daun tanaman puring bervariasi dalam hal warna daun, sehingga memiliki konsentrasi klorofil yang berbeda-beda. Daun yang tergolong muda, yakni di bagian terminal memiliki konsentrasi klorofil rendah jika dibandingkan dengan daun yang lebih tua dengan posisi di sebelah bawah daun yang muda. Hal ini disebabkan karena klorofil pada daun yang muda masih berupa protoklorofil. Daun akan berubah menjadi berwarna hijau setelah transformasi protoklorofil. Umumnya semakin tua umur daun maka konsentrasi klorofilnya akan semakin tinggi pula (Dwidjoseputo, 1980). Setiari \& Nurchayati (2009) menyatakan bahwa umur daun dan tahapan fisiologis suatu tanaman merupakan faktor yang dapat menentukan kandungan klorofil. Cahaya matahari yang diterima oleh suatu tanaman puring juga mempengaruhi warna daun puring yang bervariasi, sehingga pembentukan klorofil juga dipengaruhi oleh sinar matahari. Pigmen karotenoid berperan sebagai pigmen tambahan yang dapat membantu klorofil dalam menyerap energi cahaya.

Sumenda et al. (2011) melaporkan konsentrasi klorofil pada tingkat perkembangan daun mangga yang berbeda. Hasil penelitiannya menunjukkan bahwa daun hijau tua memiliki konsentrasi klorofil total yang lebih tinggi $(47,44 \mathrm{mg} / \mathrm{L})$ daripada daun hijau muda $(27,55 \mathrm{mg} / \mathrm{L})$. Di samping itu dalam perkembangan daun menjadi lebih tua terjadi sintesis klorofil $b$ dan klorofil a yang lebih banyak dibandingkan dengan daun yang lebih muda. Oleh sebab itu konsentrasi klorofil total pada daun yang tua lebih tinggi daripada konsentrasi klorofil total pada daun yang muda. Putri et al. (2013) juga melaporkan bahwa peningkatan kadar klorofil total pada semua jenis tanaman terjadi seiring dengan meningkatnya umur daun. Hal tersebut diamati pada tumbuhan daun pucuk merah (Syzygium oleana) yang menunjukkan bahwa semakin tua daunnya, warna daunnya cenderung berwarna hijau tua. Songke et al. (2019) juga melaporkan bahwa kandungan klorofil total pada tanaman puring berbeda akibat faktor umur (daun tua dan daun muda). Kandungan klorofil daun tua $(28,78 \pm 0,46 \mathrm{mg} / \mathrm{L})$ adalah $27,79 \%$ lebih tinggi daripada daun muda $(21,37 \pm 0,94$ $\mathrm{mg} / \mathrm{L}$ ). Hal ini menunjukkan konsentrasi klorofil pada daun yang tua lebih besar daripada daun yang muda seperti yang dilaporkan dalam penelitian ini. Daun tertua (daun pertama) pada sampel cabang ke tiga yang berwarna coklat merah lebih tinggi daripada daun yang lebih muda dengan warna daun yang bervariasi (Tabel 4).

Selanjutnya perbedaan variasi warna daun puring juga berkaitan dengan asimilasi 
antosianin, pigmentasi dengan flavonoid lain dan pembentukan kompleks dengan non logam (Papafotiou et al., 2007). Gogahu et al., (2016) melaporkan bahwa daun puring yang berwarna kuning juga masih mengandung sejumlah klorofil. Hal ini disebabkan karena klorofil daun berperan penting dalam proses fotosintesis, yaitu menyerap sinar matahari yang merupakan sumber energi dalam proses fotosintesis. Pada penelitian ini konsentrasi klorofil yang tinggi terukur pada daun yang berwarna coklat merah (diamati pada daun ke-1 dari cabang sampel 3, Tabel 4). Oleh sebab itu konsentrasi karotenoid dan antosianin yang dapat menyebabkan daun puring tersebut berwarna merah atau kuning juga perlu diukur pada penelitian selanjutnya untuk melengkapi data konsentrasi klorofil yang telah dilaporkan dalam penelitian ini.

Kandungan klorofil pada daun bervariasi dari satu jenis tanaman dengan tanaman yang lain. Kandungan klorofil bahkan bervariasi antara berbagai varietas tanaman dalam satu spesies. Kandungan klorofil pada tanaman puring bervariasi antara varietas bor merah, puring cobra, dan puring lokal. Umur daun juga mempengaruhi adanya variasi kandungan klorofil pada tanaman (Gogahu et al., 2016).

\section{KESIMPULAN}

Konsentrasi klorofil total pada daun puring bervariasi antara 3,01-33,14 $\mathrm{mg} / \mathrm{L}$, konsentrasi klorofil a bervariasi antara 0,03$3,90 \mathrm{mg} / \mathrm{L}$ dan konsentrasi klorofil b bervariasi antara 18,77-31,25 $\mathrm{mg} / \mathrm{L}$. Daun puring tua yang berwarna coklat-merah mempunyai konsentrasi klorofil yang lebih tinggi daripada daun lain dengan warna yang bervariasi.

\section{DAFTAR PUSTAKA}

Aryulina, D., C. Muslim, S. Manal, \& E. Winami. 2006. Biologi 3. Erlangga, Jakarta.

Dwidjoseputro, D. 1980. Pengantar Fisiologi Tumbuhan. Gramedia, Jakarta.

Dwidjoseputro, D. 1994. Pigmen Klorofil. Erlangga, Jakarta
Gogahu, Y., S.A. Nio, \& P Siahaan. 2016.

Konsentrasi Klorofil pada Beberapa Varietas Tanaman Puring (Codiaeum variegatum L.). Jurnal MIPA UNSRAT Online, 5(2): 76-80.

Kumari, K., S.P. Kiran, Y.S. Vani, V. Sridevi, \& M.V.V. Chandana Lakshmi. 2012. Separation and Observation of Plant Pigments in Fertilizers Affected Medicinal Plants Using Paper Chromatography. Journal Engineering Science \& Advanced Technology, 2(2): 317-326.

Mustafa, N., N. Ya'acob, Z. A. Latif, \& A.L. Yusof. 2015. Quantification of Oil Palm Tree Leaf Pigment (Chlorophyll A) Concentration Based on Their Age. Jurnal Teknologi, 7(5): 129-134.

Muzayyinah. 2003. Keragaman Puring (Codiaeum varigatum L.) di Daerah Istimewa Yogyakarta. Jurnal Biodiversitas, 4(1): 43-46.

Nio, S.A., B.J. Kolondam, \& T.E. Tallei. 2018. Evaluation of matK and rbcL Genes as Markers in DNA Barcoding of (Codiaeum variegatum L.) Blume. Journal Bioscience Research, 15(1): 192-198.

Papafotiou, M,, B. Avajianneli, \& M. Costas. 2007. Coloration, Anthocyanin Concentration and Growth of Croton (Codiaeum varigatum L.) as Affected by Cotton Gin Trash Compost Use in the Potting Medium. Hortscience, 42(1): 8387.

Pratama, A.J. \& A.N. Laily. 2015. Analisis Konsentrasi Klorofil Gandasuli (Hedychium gardnerium Shepard ex Ker-Gawl) pada Tiga Daerah Perkembangan Daun yang Berbeda. Prosiding Seminar Nasional Konservasi dan Pemanfaatan Sumber Daya Alam Pendidikan Biologi, Pendidikan Geografi, Pendidikan Sains, PKLHFKIP UNS 2015: 216-219.

Putri, W.D.R., E. Zubaidah, \& N. Sholahudin. 2013. Ekstraksi Pewarna Alami Daun Suji, Kajian Pengaruh Blanching dan Jenis Bahan Pengekstrak. Jurnal Teknik Pertanian, 4(1): 13-24. 
Sasmitamihardja, D. 1990. Penuntun Praktikum Fisiologi Tumbuhan. ITB, Bandung.

Setiari, N. \& Y. Nurchayati. 2009. Eksplorasi Konsentrasi Klorofil pada Beberapa Sayuran Hijau sebagai Alternatif Bahan Dasar Suplemen Makanan. Jurnal Bioma, 11(1): 6-10.

Songke, N.G., P. Siahaan, \& S.A. Nio. 2019. Kandungan Klorofil Total Daun Puring (Codiaeum variegatum L.) yang Mengalami Cekaman Kekeringan. Jurnal MIPA UNSRAT Online, 8(2): 5558.

Sukendro, A., \& E. Sugiarto. 2012. Respon Pertumbuhan Anakan Shorea leprosula Miq., Shorea selanica Ridlex, Shorea ovali (Korth) Blume dan Shorea selania (DC) Blume terhadap Tingkat Intensitas Cahaya Matahari. Jurnal Silvikultur Tropikal, 03(1): 22-27.
Sumanta, N., C. I. Haque, J. Nishika, \& R. Suprakash. 2014. Spectrophotometric Analysis of Chlorophylls and Carotenoids from Commonly Grown Fern Species by Using Various Extracting Solvents. Journal Chemical Sciences, 4(9): 63-69.

Sumenda, L., H.L. Rampe, \& F.R. Mantiri. 2011. Analisis Konsentrasi Klorofil Daun Mangga (Mangifera indica L.) pada Tingkat Perkembangan Daun yang Berbeda. Jurnal Bioslogos, 1(1): 21-24.

Upadani, W, D,P, Darmawan, \& I.N. Tenaya. 2013. Strategi Pengembangan Agribisnis Puring di Desa Petiga, Kecamatan Marga Kabupaten Tabanan. Jurnal Manajemen Agribisnis, 1(2): 6774.

Webster, G.L. 1992. Realignments in American Croton (Euphorbiaceae). Jurnal Novon, 2(3): 269-273. 